\title{
PENGARUH MODEL RANCANGAN IDI TERHADAP PRESTASI BELAJAR PESERTA DIDIK IPS EKONOMI DI KELAS VII MTS.MUHAMMADIYAH 22 PADANGSIDIMPUAN TAHUN PELAJARAN 2017-2018
}

\author{
Drs.Ali Nurdin Siregar MA \\ Dosen FKIP Univeristas Muhammadiyah Tapanuli Selatan
}

\begin{abstract}
Abstrak
Dalam penelitian ini penulis menggunakan metode penelitian lapangan (field research) dan penelitian kepustakaan (library research). Alat pengumpulan data yang penulis lakukan adalah dengan melakukan angket dan tes. Kemudian untuk melihat apakah ada pengaruh model rancangan IDI terhadap prestasi belajar peserta didik IPS Ekonomi di kelas VII MTs. Muhammadiyah 22 Padangsidimpuan, Penulis menggunakan rumus statistik yaitu korelasi product moment, yaitu :

$$
r_{x y}=\frac{\sum x y}{\sqrt{\left(\sum x^{2}\right) \cdot\left(\sum y^{2}\right)}}
$$

Dari perhitungan koefesien korelasi ganda tersebut maka diperoleh hasil $r$ hitung $=0,432$, hasil ini kemudian dibandingkan dengan $r_{\text {tabel }}$ dimana $r_{\text {hitung }}$ lebih besar dari $r_{\text {tabel }}$ yaitu $0,432>0,37$, maka dapat dikatakan bahwa terdapat pengaruh model rancangan IDI terhadap prestasi belajar peserta didik IPS Ekonomi di kelas VII MTs. Muhammadiyah 22 Padangsidimpuan Tahun Pelajaran 2017-2018.
\end{abstract}

Kata Kunci: Prestasi Belajar, Model Pembelajaran, Peserta Didik

\section{Pendahuluan}

Model pembelajaran mempunyai makna yang lebih luas dari pada strategi, metode atau prosedur pembelajaran. Istilah model pembelajaran mempunyai 4 ciri khusus yang tidak dipunyai oleh strategi atau metode pembelajaran :

a. Rasional teoritis yang logis yang disusun oleh pendidik.

b. Tujuan pembelajaran yang akan dicapai

c. Langkah-langkah mengajar yang diperlukan agar model pembelajaran dapat dilaksanakan secara optimal.

d. Lingkungan belajar yang diperlukan agar tujuan pembelajaran dapat dicapai. 
Pengembangan sistem pembelajaran (instruksional) merupakan salah satu bentuk pembaharuan sistem instruksional yang banyak dilakukan dalam rangka pembaharuan sistem pendidikan, dengan maksud agar sistem tersebut dapat lebih serasi dengan tuntutan kebutuhan masyarakat, serasi pula dengan perkembangan ilmu pengetahuan dan teknologi. Tujuan utama meningkatkan produktivitas dan efisiensi proses pembelajaran.

Namun demikian, pendekatan yang sistematis dalam kegiatan instruksional ini dilakukan dengan cara yang berbeda-beda, dan dengan sebutan yang berbeda-beda pula. Sebutan itu di antaranya adalah pengembangan instruksional, desain instruksional, pengembangan sistem instruksional, pengembangan program instruksional, pengembangan produk instruksional, pengembangan organisasi, dan pengembangan kemampuan mengajar. Tetapi istilah populer yang lazim digunakan adalah "pengembangan instruksional (pembelajaran), yang merupakan padanan dari istilah "instructional development". Istilah yang disebutkan terakhir ini adalah merupakan istilah resmi yang dibakukan oleh organisasi profesi AECT (Association for Educational Communication and Technology) di Amerika Serikat.

Dalam operasionalnya pengembanga $\mathrm{n}$ sistem intruksional ini dapat dilaksanakan untuk jangka pendek maupun jangka panjang; dapat dilaksanakan untuk satu topik sajian, satu periode latihan, satu semester, satu bidang studi, atau bahkan satu sistem yang lebih besar lagi.
Desain pembelajaran dapat dimaknai dari berbagai sudut pandang, misalnya sebagai disiplin, sebagai sistem, dan sebagai proses. Sebagai disiplin, desain pembelajaran membahas berbagai penelitian dan teori tentang strategi serta proses pengembangan pembelajaran dan pelaksanaannya. Sebagai ilmu, desain pembelajaran merupakan ilmu untuk menciptakan spesifikasi pengembangan, pelaksanaan, penilaian, serta pengelolaan situasi yang memberikan fasilitas pelayanan pembelajaran dalam skala makro dan mikro untuk berbagai mata pelajaran pada berbagai tingkatan kompleksitas.

Istilah belajar dan pembelajaran merupakan suatu istilah yang memiliki keterkaitan yang sangat erat dan tidak dapat dipisahkan satu sama lain dalam proses pendidikan. Pembelajaran seharusnya merupakan kegiatan yang dilakukan untuk menciptakan suasana atau memberikan pelayanan agar peserta didik belajar. Untuk itu, harus dipahami bagaimana peserta didik memperoleh pengetahuan dari kegiatan belajarnya. Jika guru dapat memahami proses pemerolehan pengetahuan, maka guru akan dapat menentukan model pembelajaran yang tepat bagi peserta didiknya. Menurut Sudjana dalam Sugihartono, dkk "pembelajaran merupakan setiap upaya yang dilakukan dengan sengaja oleh pendidik yang dapat menyebabkan peserta didik melakukan kegiatan belajar, Sedangkan Nasution mendefinisikan "pembelajaran sebagai suatu aktifitas mengorganisasi atau mengatur lingkungan sebaik-baiknya dan menghubungkannya dengan anak didik sehingga terjadi proses belajar, Lingkungan dalam pengertian ini 
tidak hanya ruang belajar, tetapi juga meliputi guru, alat peraga, perpustakaan, laboratorium, dan sebagainya yang relevan dengan kegiatan belajar peserta didik.

Trianto mengatakan bahwa "model pembelajaran adalah suatu perencanaan atau suatu pola yang digunakan sebagai pedoman dalam merencanakan pembelajaran di kelas, Model pembelajaran mengacu pada pendekatan pembelajaran yang akan digunakan, termasuk di dalamnya tujuan-tujuan pengajaran, tahap-tahap dalam kegiatan pembelajaran, lingkungan pembelajaran, dan pengelolaan kelas. Selanjutnya Dimiyati mengatakan bahwa Model pembelajaran adalah "kerangka konseptual yang melukiskan prosedur yang sistematis dalam mengorganisasikan pengalaman belajar peserta didik untuk mencapai tujuan belajar tertentu, dan berfungsi sebagai perencanaan pembelajaran" Memperhatikan beberapa pengertian model pembelajaran di atas, dapat disimpulkan bahwa model pembelajaran merupakan cara-cara yang akan dipilih dan digunakan oleh seorang pendidik untuk menyampaikan materi pembelajaran sehingga akan memudahkan peserta didik menerima dan memahami materi pembelajaran. Dalam arti luas Model Pembelajaran adalah merupakan deskripsi dari lingkungan belajar yang menggambarkan perencanaan kurikulum, kursus-kursus, rancangan unit pembelajaran, perlengkapan belajar, buku-buku pelajaran, program multimedia, dan bantuan belajar melalui komputer.

Berdasarkan fenomena diatas, maka penulis tertarik melakukan penelitian dengan judul "Pengaruh Model Rancangan IDI Terhadap Prestasi Belajar Peserta Didik IPS Ekonomi di Kelas VII MTs.Muhammadiyah 22 Padangsidimpuan Tahun Pelajaran 2017$2018 \%$.

\section{Metode Penelitian}

Pendekatan penelitian yang digunakan adalah pendekatan kuantitatif. Penelitian kuantitatif yang dilandasi pada suatu asumsi bahwa suatu gejala itu dapat diklasifikasikan, dan hubungan gejala bersifat kausal (sebab akibat). Jadi dalam penelitian ini penulis menggambarkan dua variabel penelitian yaitu rancangan model pembelajaran IDI (variabel $\mathrm{X}$ ) dan prestasi belajar IPS Ekonomi pada materi pokok tindakan dan prinsip ekonomi (varibel Y).

Metode penelitian yang dilakukan dalam penelitian ini adalah :

1. Penelitian Kepustakaan (Library Research, yaitu penelitian yang dilakukan dengan melihat sumber-sumber bacaan seperti, buku, buletin, koran, majalah, dan sumber-sumber lainnya yang berkenaan dengan variabel penelitian.

2. Penelitian Lapangan (Field Research), yaitu penelitian yang dilakukan dengan secara langsung ke lokasi penelitian yaitu MTs. Muhammadiyah 22 Padangsidimpuan.

Secara umum prosedur penelitian dapat dibagi menjadi tiga tahap yaitu tahap persiapan, pelaksanaan dan penyelesaian.

1. Tahap Persiapan, terdiri dari :

a. Menentukan lokasi penelitian;

b. Menghubungi pihak sekolah dan guru bidang studi IPS Ekonomi; 
c. Menyusun rencana pelaksanaan dan identifikasi masalahnya.

d. Melaksanakan proses penelitian langsung ke objek

2. Tahap pelaksanaan, terdiri dari :

a. Memberi orientasi peserta diri kepada peserta didik tentang manfaat dan tujuan pengambilan data-data variabel;

b. Menyebarkan instrumen penelitian berupa angket dan tes hasil belajar.

3. Tahap Akhir, terdiri dari :

a. Mengumpulkan kembali instrumen angket dan tes untuk ditabulasi jawabannya;

b. Mengolah dan menganalisis data;

c. Menarik kesimpulan berdasarkan hasil yang diperoleh dari pengolahan data.

\section{Pembahasan dan Hasil}

Berdasarkan hasil penelitian yang dilakukan, data yang diperoleh terdiri dari dua sumber yaitu melalui angket dan tes. Angket yang disebarkan adalah guna untuk mengumpulkan data tentang model rancangan pembelajaran IDI (variabel X) Sedangkan tes digunakan untuk mengetahui prestasi yang dicapai peserta didik pada bidang studi IPS-Ekonomi materi pokok tindakan dan prinsip ekonomi (variabel Y) di VII MTs. Muhammadiyah 22 Padangsidimpuan Tahun Pelajaran 20172018.

Berdasarkan hasil jawaban peserta didik kelas VII MTs. Muhammadiyah 22 Padangsidimpuan terhadap angket tentang tingkat ekonomi keluarga dengan ketentuan nilai sebagai berikut :

a. Untuk jawaban Ya diberi nilai 3;
b.Untuk jawaban Kadang-Kadang diberi nilai 2;

c. Untuk jawaban Tidak diberi nilai 1.

Untuk mengolah angket penulis menggunakan rumus persentase yaitu :

$p=\frac{f}{N} x 100 \%$

Keterangan :

$\mathrm{P}=$ Persentasi option yang dijawab responden

$\mathrm{F}=$ Frekwensi jawaban responden atas opsi yang ditawarkan

$\mathrm{N}=$ Jumlah sampel

Adapun data yang diperoleh dari penyebaran angket kepada responden sebagai berikut :

Tabel 1

Apakah Guru Bidang Studi IPS Ekonomi Mempunyai Rancangan Pembelajaran Yang Baik?

\begin{tabular}{|c|c|c|c|}
\hline No & $\begin{array}{c}\text { Alternatif } \\
\text { Jawaban }\end{array}$ & frekwensi & $\frac{f}{N} \times 100 \%$ \\
\hline 1. & $\begin{array}{c}\text { Kadang- } \\
\text { Kadang } \\
\text { Tidak }\end{array}$ & 0 & $100 \%$ \\
& Jumlah & 28 & $100 \%$ \\
\hline
\end{tabular}

Berdasarkan tabel diatas dapat disimpulkan bahwa guru bidang studi IPS Ekonomi mempunyai rancangan pembelajaran yang baik, hal ini terlihat dari jawaban yang 
diberikan yaitu menjawab ya sebanyak 28 peserta didik (100\%).

Tabel 2

Apakah Proses Pembelajaran Yang Dilaksanakan Guru Bidang Studi IPS Ekonomi Terlaksana Dengan Baik Sesuai Perencanaan Yang Telah Disusunnya?

\begin{tabular}{|c|c|c|c|}
\hline No & $\begin{array}{c}\text { Alternatif } \\
\text { Jawaban }\end{array}$ & frekwensi & $\frac{f}{N} \times 100 \%$ \\
\hline \multirow{2}{*}{2.} & Ya & 24 & $85,71 \%$ \\
& $\begin{array}{c}\text { Kadang- } \\
\text { Kadang } \\
\end{array}$ & 1 & $3,57 \%$ \\
& Tidak & 3 & $10,71 \%$ \\
\hline & Jumlah & 28 & $100 \%$ \\
\hline
\end{tabular}

Berdasarkan tabel diatas dapat disimpulkan bahwa proses pembelajaran yang dilaksanakan guru bidang studi IPS Ekonomi terlaksana dengan baik sesuai dengan perencanaan yang telah disusunnya, hal ini terlihat dari jawaban yang diberikan yaitu menjawab ya sebanyak 24 peserta didik $(85,71 \%)$, yang menjawab kadangkadang sebanyak 1 peserta didik $(3,57 \%)$ dan yang menjawab tidak sebanyak 3 peserta didik $(10,71 \%)$.

Dalam perhitungan persentase yang dilakukan melalui angket dan tes, dimana variabel $\mathrm{X}$ (model rancangan pembelajaran IDI) diperoleh rata-rata 25,43 dan variabel Y (prestasi belajar peserta didik dalam bidang studi ekonomi materi pokok tindakan dan prinsip ekonomi) diperoleh nilai rata-rata 73,21. Seterusnya dilakukan analisis data dengan menggunakan rumus korelasi product moment, yaitu $r_{x y}$ hitung $=0,432$. Nilai ini kemudian dibandingkan dengan nilai $\mathrm{r}_{\mathrm{xy}}$ tabel, dimana $\mathrm{N}=28$ peserta didik pada taraf kesalahan $5 \%$ adalah 0,374 .

Nilai $r_{\text {hitung }}$ lebih besar dari nilai $r_{\text {tabel }}(0,432>0,374)$, hal ini menunjukkan bahwa terdapat pengaruh model rancangan IDI terhadap prestasi belajar peserta didik IPS Ekonomi di kelas VII MTs. Muhammadiyah 22 Padangsidimpuan Tahun Pelajaran 2017-2018.

\section{Kesimpulan}

Berdasarkan pembahasan masalah penelitian diatas, dimana dilakukan analisis data dengan perhitungan persentase dan diuji melalui perhitungan koefisien korelasi product moment, diperoleh nilai $r_{x y}$ hitung sebesar 0,432 dan $r_{x y}$ table dengan $\mathrm{N}=28$ pada taraf kesalahan $5 \%$ adalah 0,374 . Nilai

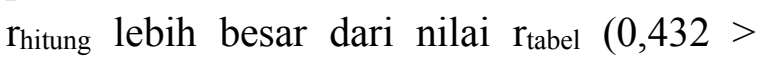
0,374). Jadi dapat disimpulkan bahwa terdapat pengaruh model rancangan IDI terhadap prestasi belajar peserta didik IPS Ekonomi di kelas VII MTs. Muhammadiyah 22 Padangsidimpuan Tahun Pelajaran 20172018.

\section{Saran}

Sehubungan dengan penelitian yang telah penulis lakukan, peneliti memberikan saran sebagai berikut:

1. Berdasarkan hasil analisa data diatas, maka model rancangan pembelajaran IDI dapat meningkatkan motivasi dan prestasi belajar peserta didik. Untuk itu disarankan kepada guru bidang studi IPS Ekonomi khususnya agar dapat memperhatikan model pembelajaran yang akan digunakan dalam proses 
pembelajaran demi tercapainya tujuan yang diinginkan

2. Disamping itu juga, disarankan kepada guru bidang studi IPS Ekonomi agar senantiasa memperhatikan kondisi fisik dan psikis peserta didik sebelum memulai pembelajaran.

3. Guru bidang studi IPS Ekonomi agar senantiasa memberikan motivasi dan dorongan kepada peserta didik untuk senantiasa belajar dengan baik dan sungguh- sungguh.

\section{Daftar Pustaka}

Anwar Sanusi, 2011, Metodologi Penelitian Bisnis, Penerbit Salemba Empat; Jakarta

Abdurrahman, 2001, Pendidikan Bagi Anak Berkesulitan Belajar, Rineka Cipta, Jakarta

Dimiyati, 2006, Belajar dan Pembelajaran, Jakarta : Rineka Cipta

Hasbullah. 2003, Dasar-Dasar Ilmu Pendidikan. Jakarta: PT Raja Grafindo

Hamzah B. Uno, 2009, Perencanaan Pembelajaran, Jakarta : Salemba Empat

Harjanto, 2007, Perencanaan Pengajaran, Jakarta : Rineka Cipta

Hamalik, Oemar, 2003, Proses Belajar Mengajar, Bandung, Bumi Aksara

Juliansyah, 2010, Ekonomi Untuk SMP, Jakarta; Rineka Cipta
Kartini. Kartono. 2000, Peranan Keluarga Berencana Memandu Anak. Jakarta: CV Rajawali

M.Firdaus Zarkasi, 2009, Belajar Cepat dengan Diskusi, Malang, Indah Surabaya

Muhammad Ali, 2002, Penelitian Kependidikan Prosedur dan Strategi, Bandung : Angkasa

Nasution, 2007, Belajar dan Pembelajaran, Yogyakata: UII Press

Pusat Bahasa Depdiknas. 2005, Kamus Besar Bahasa Indonesia, Edisi Ketiga. Jakarta: Balai Pustaka

Sardiman, 2005, Model Desain dalam Pembelajaran. Bandung: Sinar Baru

Surakhmad, Winarno, 2009, Pengantar Metode Penelitian, Bandung : Tarsito

Sugiyono, 2006, Metodologi Penelitian \& Research, Jakarta : Alfabeta

Sugihartono, 2007, Model-Model Pembelajaran, Jakarta ; Sumber Media

Syaiful Sagala, 2006, Belajar dan Pembelajaran, Jakarta ; Balai Pustaka

Sri Rumini, 2006, Psikologi Pendidikan, Yogyakarta ; UNY Pers

Syaiful Bahri, 2005, Strategi Belajar Mengajar, Salemba Empat, Jakarta 